Creative commons User License: CC BY-NC-ND

Abstracted by: EBSCOhost, Electronic Journals Service (EJS), Google Scholar, Journal Seek, Scientific Commons,

Food and Agricultural Organization (FAO), CABI and Scopus
Journal of Agricultural Extension

Vol. 22 (1) February, 2018

ISSN(e): 24086851; ISSN(Print); 1119944X

http://journal.aesonnigeria.org

http://www.ajol.info/index.php/jae

Email: editorinchief@aesonnigeria.org

\title{
Constraints to Women Farmers' Entrepreneurial Development in Nasarawa State, Nigeria
}

https://dx.doi.org/10.4314/jae.v22i1.5

\author{
Kagbu, Joyce. Hauwa. \\ Department of Agricultural Extension and Economics, \\ National Agricultural Extension and Research Liaison Services, \\ Ahmadu Bello University, Zaria \\ Email: kkagbu@gmail.com, Phone: +2348133344843
}

\section{Abstract}

This study examined the entrepreneurial competencies among women farmers in Nasarawa State, Nigeria. Specifically, this paper described the characteristics of the respondents, identified the characteristics (type, form and duration) of enterprises the respondents engaged in, and examined their constraints to entrepreneurial development. Structured interview schedule was used to collect relevant information from 165 women farmers selected through multi-stage sampling procedure across 6 local government areas of Nasarawa State. Descriptive statistics (percentages and mean) were used to analyze the data. Most (82.8\%) of the women entrepreneur were married, and had less than secondary education (82.3\%). Also the mean age, household size and annual income was 39, 8 and $\$ 208,759.38$ respectively. Furthermore, the majority (81\%) did not belong to their respective business associations. Processing was the major type of business engaged in by many (58.8\%) as sole proprietor (87.9\%). Persistence, commitment to work contract, and risktaking ranked highest with a mean score of 2.55, 2.47 and 2.40, respectively among the women entrepreneurial characteristics. Lack of start-up capital (95\%), poor infrastructural facilities (93\%), and inadequate access to relevant information (89\%) were the major constraints to women farmers' entrepreneurial development. Various tiers of government should create the enabling social and physical infrastructure environments to catalyze entrepreneurial development (with special focus for women) in the rural areas.

Key words: Entrepreneurial development, women entrepreneurial challenges.

\section{Introduction}

It has been noted that women entrepreneurs have low business performance compared to their male counterparts (Akanji, 2001). If Nigeria wants to reach its full potential in terms of economic and social developments, it cannot afford to ignore the importance of its indigenous entrepreneurs (especially indigenous women entrepreneurs) and the contributions that they make to the country's economy. Entrepreneurship remains the gateway to sustainable wealth creation in Nigeria (Ogundele, Akingbade and Akinlabi, 2012; Nkpoyen and Bassey, 2012; Nwala, 2013; Idris, 2015). Also, if Nigeria desires to 
Creative commons User License: CC BY-NC-ND

Abstracted by: EBSCOhost, Electronic Journals Service (EJS), Google Scholar, Journal Seek, Scientific Commons,

Food and Agricultural Organization (FAO), CABI and Scopus
Journal of Agricultural Extension

Vol. 22 (1) February, 2018

ISSN(e): 24086851; ISSN(Print); 1119944X

http://journal.aesonnigeria.org

http://www.ajol.info/index.php/jae

Email: editorinchief@aesonnigeria.org

move out of the high level of unemployment and ravaging poverty, adequate attention must be given to the growth of self-employment and better still women entrepreneurship (Matanmi and Awodun, 2005; Nkpoyen and Bassey, 2012).

Academics and government appear to be focused on entrepreneurship, because it symbolizes innovation and a dynamic economy. Female entrepreneurs have been identified as a major force for innovation, job creation and economic growth (OECD, 1997; OECD, 2013). This finding has spurned a lot of researches into women's ownership of agribusiness enterprises. Many women are entrepreneurs. However, the global impact of female entrepreneurs is just beginning to gain intensity. The number of female business owners continues to increase steadily worldwide and it is estimated that firms owned by women account for between 25 and 33\% of all businesses (Carter, 2000; Carter and Rosa, 1998).

In some regions of the world, transformation to a market economy threatens to deepen gender inequality. Some of these changes are simply the legacy of a gender imbalance that exists prior to political and economic returns. Other changes reflect a return to traditional norms and value that relegated women to a secondary position. As countries become more democratic and gender inequalities lessen, more productive atmosphere for both sexes is provided (Allens and Truman, 1992; Anna, Chandler, Janson and Mero, 2000). Women's productive activities, particularly in industries that empower them economically and enable them to contribute more to overall development; whether they are involved in small or medium scale production activities, or in the informal or formal sectors, are not only a means for economic survival but also have positive social influences for the women themselves and their social environment (UNIDO, 2001).

In many societies women do not enjoy same opportunities as men. In many transitional economies, progress has been achieved in opening doors to education and health protection for women but political and economic opportunities for female entrepreneurs have remained limited. Concerted efforts are needed to enable female entrepreneurs to make better economic choices and to transform their businesses into competitive enterprises and high-generating income economic activities (OECD, 1997). Entrepreneurship represents an appropriate opportunity for women all over the world, as entrepreneurship responds flexibly to entry, change and innovation. This potential has not yet been realized in an optimal fashion in most developing countries. A large number of women work in the informal sector but their contribution is not included in rational accounts (UNIDO, 1995). There are a variety of constraints on women and the ability of women to upgrade their production continuously. These include poor access to market information, technology and finance, as well as poor linkages with support services and an unfavorably policy and regulatory environment (UNIDO, 2001). These constraints were neither ranked nor location-specific. Although many of the constraints are shared by both female and male entrepreneurs, women entrepreneurs face 
Creative commons User License: CC BY-NC-ND

Abstracted by: EBSCOhost, Electronic Journals Service (EJS), Google Scholar, Journal Seek, Scientific Commons,

Food and Agricultural Organization (FAO), CABI and Scopus
Journal of Agricultural Extension

Vol. 22 (1) February, 2018

ISSN(e): 24086851; ISSN(Print); 1119944X

http://journal.aesonnigeria.org

http://www.ajol.info/index.php/jae

Email: editorinchief@aesonnigeria.org

additional obstacles; this is due to deeply rooted discriminatory socio-cultural values and traditions embedded, particularly in the policy and legal environment as well as in institutional support mechanism. In many instances, women are unable to benefits from services and must struggle to overcome or circumvent discriminations in business circles (UNIDO, 2001).

Previous gender studies in Nigeria on entrepreneurship focused more on the traits and characteristics. Nwibo and Okorie (2013) examined the constraints to entrepreneurship among investors in South-east Nigeria. The study was not particularly focused on women. There is indeed inadequate empirical work investigating the constraints faced by women in developing their enterprises in Nigeria. It is therefore important to explore the entrepreneurial development constraints and related issues, especially as they hinder women entrepreneurial development in Nigeria with particular reference to Nasarawa state. Specifically, the paper:

i. described the characteristics of the respondents;

ii. identified the enterprise characteristics (type, form and duration) of the respondents;

iii. examined the entrepreneurial competencies of women entrepreneurs, and

iv. identified the constraints to women entrepreneurial development.

\section{Methodology}

Nasarawa State has 13 Local Government Areas. Its women population was put at 925,576 people (National population Commission [NPC], 2006) and had a projected population of $1,251,378$ people in 2016 using an annual growth rate of $3.2 \%$. The selected Local Government Area used for the study area is depicted in Figure 1. Nasarawa State is bounded in the north by Kaduna State, in the west by the Federal Capital Territory (Abuja), in the south by Kogi and Benue States and in the east by Taraba and Plateau States. The State is located in Southern Guinea Savanna belt of the country and occupies a total land area of 28,682 square kilometers. It has agriculture as the mainstay of its economy with the production of varieties of cash crops throughout the year. The State is predominantly agrarian with the majority of the population actively involved in farming. Other food crops produced within the study area apart from rice include yam, beniseed, sorghum, melon, cassava, cowpea and maize (NADP, 2010). 


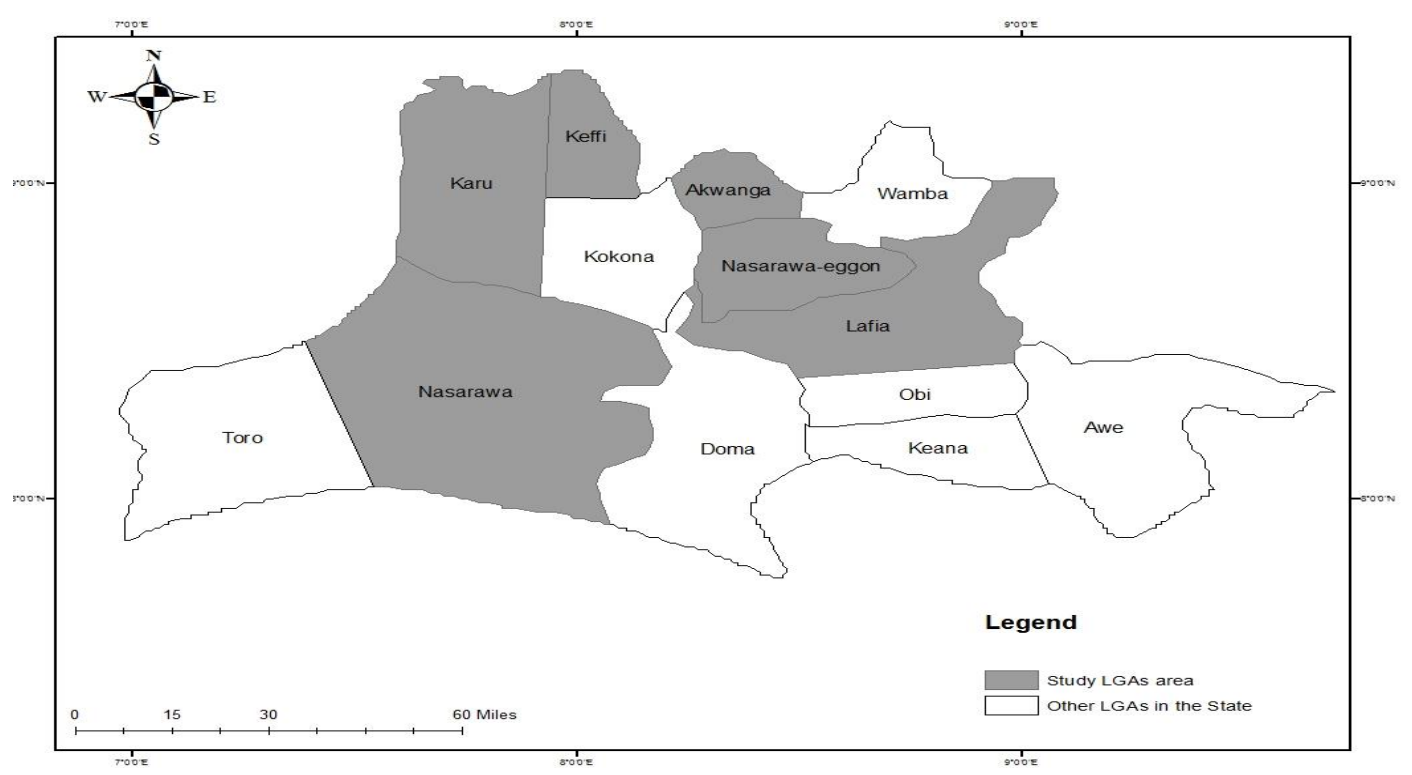

Figure 1: Map of Nasarawa State showing the study area

Women entrepreneurs in Nasarawa State constitute the population of the study. Multistage sampling procedure was used to select the women entrepreneurs for this study. The first stage was the purposive selection of six LGAs from the State. A reconnaissance survey was conducted to establish a sample frame of 1,096 women farmer entrepreneurs across the six LGAs thus: Akwanga (192), Karu (146), Keffi (200), Lafia (220), Nasarawa (186) and Nasarawa-Eggon (152). The second stage was a purposive selection of two prominent villages in each Local Government Area. The selection in the first and second stage was based on the high presence of women entrepreneurs as shown by the reconnaissance survey. The third stage was random selection of women entrepreneur in the selected villages. Fifteen percent of the women entrepreneurs were selected per village. In all, a total of 165 women entrepreneurs \{Akwanga (29), Karu (22), Keffi (30), Lafia (33), Nasarawa (28) and Nasarawa-Eggon (23)\} were used for this study.

Primary data were used for this study. The primary data were collected through the use of structured interview schedule which was administered on the respondents. Women entrepreneurs were visited by trained enumerators to collect relevant data. Descriptive statistics were employed to analyze the data collected. Competency in entrepreneurial characteristics was measured as high (3), moderate (2) or low (1) in ten (10) major characteristics. Competency score was computed for all the respondents with respect to each characteristic. Mean competency was obtained by summing up the score for each respondent. As a decision rule, for each characteristic, a mean competency greater than 2 was regarded as 'competent' while a mean competency less than 2 was regarded as 'not competent'. For measurement of constraints, respondents were 
Creative commons User License: CC BY-NC-ND

Abstracted by: EBSCOhost, Electronic Journals Service (EJS), Google Scholar, Journal Seek, Scientific Commons,

Food and Agricultural Organization (FAO), CABI and Scopus
Journal of Agricultural Extension

Vol. 22 (1) February, 2018

ISSN(e): 24086851; ISSN(Print); 1119944X

http://journal.aesonnigeria.org

http://www.ajol.info/index.php/jae

Email: editorinchief@aesonnigeria.org

required to indicate 'yes' or 'no' for each of the eleven constraints. Responses (scored 1 and 0 , respectively) were summed up according to the number of respondents who indicated 'yes' for each constraint. This was recorded as percentage of the total number of respondents.

\section{Results and Discussion}

\section{Socio-economic characteristics of women farmers}

Table 1 shows the socio-economic characteristics of women entrepreneur. The mean age of the women was 39. This implies that women entrepreneurs were at their middle and productive age hence would have the energy required in managing an enterprise. The majority $(82.8 \%)$ of women entrepreneurs were married, and had less than secondary education (82.3\%). While being married might denotes high entrepreneurial responsibility; poor education might imply low entrepreneurial competency. Also the mean household size and annual income was 8 and $\$ 208,759.38$ respectively. Furthermore, the majority ( $81 \%)$ did not belong to their respective business association. 
Creative commons User License: CC BY-NC-ND

Abstracted by: EBSCOhost, Electronic Journals Service (EJS), Google Scholar, Journal Seek, Scientific Commons,

Food and Agricultural Organization (FAO), CABI and Scopus
Journal of Agricultural Extension

Vol. 22 (1) February, 2018

ISSN(e): 24086851; ISSN(Print); 1119944X

http://journal.aesonnigeria.org

http://www.ajol.info/index.php/jae

Email: editorinchief@aesonnigeria.org

Table 1: Distribution of women farmers based on socio-economic characteristics

\begin{tabular}{|c|c|c|}
\hline Variables & Percentage $(n=165)$ & Mean $(\bar{x})$ \\
\hline \multicolumn{3}{|l|}{ Age (years) } \\
\hline Equal or $<20$ & 2.3 & 39 \\
\hline $21-40$ & 51.7 & \\
\hline $41-60$ & 33.1 & \\
\hline$>60$ & 9.9 & \\
\hline \multicolumn{3}{|l|}{ Marital Status } \\
\hline Married & 82.8 & \\
\hline Single & 2.9 & \\
\hline Divorced & 2.5 & \\
\hline Widowed & 11.8 & \\
\hline \multicolumn{3}{|l|}{ Education } \\
\hline No Formal Education & 10.3 & \\
\hline Adult Education & 33.3 & \\
\hline Primary Education & 38.7 & \\
\hline Secondary Education & 14.7 & \\
\hline Tertiary Education & 2.5 & \\
\hline Household Size & & 8 \\
\hline$<6$ & 32.4 & \\
\hline $6-10$ & 51.4 & \\
\hline$>10$ & 16.2 & \\
\hline \multicolumn{3}{|c|}{ Membership of business association } \\
\hline Belong & 81.0 & \\
\hline Do not belong & 19.0 & \\
\hline Farm Size (Ha) & & 1.5 \\
\hline$<2$ & 47.1 & \\
\hline $2-4$ & 39.5 & \\
\hline$>4$ & 13.4 & \\
\hline \multicolumn{3}{|l|}{ Income (\$/annum) } \\
\hline Below 200,000 & 27.4 & $208,759.38$ \\
\hline $200,000-500,000$ & 42.4 & \\
\hline Above 500,000 & 30.2 & \\
\hline
\end{tabular}

*Multiple responses 
Creative commons User License: CC BY-NC-ND

Abstracted by: EBSCOhost, Electronic Journals Service (EJS), Google Scholar, Journal Seek, Scientific Commons,

Food and Agricultural Organization (FAO), CABI and Scopus
Journal of Agricultural Extension

Vol. 22 (1) February, 2018

ISSN(e): 24086851; ISSN(Print); 1119944X

http://journal.aesonnigeria.org

http://www.ajol.info/index.php/jae

Email: editorinchief@aesonnigeria.org

\section{Enterprise Characteristics}

Most of the respondents were micro-entrepreneurs, and were dominated by processing type of business (58.8\%). This result indicates women preference in processing activities. Form of enterprise was single owned (sole proprietorship) (87.9\%). This finding could be due to the small-scale nature of women entrepreneurship in the study area. In addition, the experienced firms ffirms have established for 4 or more than 4 years (Ruangkrit and Thechatakerng, 2015)\} were in the majority (76\%). Long years of experience could be an indication of resilience of women in entrepreneurial activities.

Table 2: Characteristics of enterprise by type, form and duration*

\begin{tabular}{lll}
\hline Variables & Description & $\%(\mathbf{n}=\mathbf{1 6 5})$ \\
\hline Major type of business & Production & 17.6 \\
& Processing & 58.8 \\
& Marketing & 23.6 \\
Forms of business* & Sole proprietorship & 87.9 \\
& Partnership & 63.0 \\
Duration of business & Cooperative & 28.9 \\
& $<4$ & 21.8 \\
& $4-10$ & 52.7 \\
& $>10$ & 25.5 \\
\hline
\end{tabular}

${ }^{*}$ Multiple responses

\section{Entrepreneurial Competencies of Respondents}

Competencies of women in the entrepreneurial characteristics were examined (Table 3). Persistence $(\bar{x}=2.55)$, commitment to work contract $(\bar{x}=2.47)$, and risk-taking $(\bar{x}=2.40)$ ranked highest Persistence is the quality, which enables the entrepreneurs to develop determination to have a thorough job done at any cost in terms of personal sacrifice. By doing this, the entrepreneur remains working towards the achievement of his/her set goals. Also, respondents were committed to the work contract $(\bar{x}=2.47)$. Commitment to the work contract is the ability to accept final responsibility for completing a job for the customers. Customers expect entrepreneurs to perform and to honor their commitments. It follows therefore; that the entrepreneur should do everything possible to ensure that he/she fulfils the commitment with his/her customers. It means joining the workers to work with them to ensure that contractual commitments are fulfilled.

With respect to risk-taking, entrepreneurs are people who prefer taking moderate risks. Before they commit themselves and their resources, they assess the risks that are associated with a business opportunity that they have selected, and their ability to 
Creative commons User License: CC BY-NC-ND

Abstracted by: EBSCOhost, Electronic Journals Service (EJS), Google Scholar, Journal Seek, Scientific Commons,

Food and Agricultural Organization (FAO), CABI and Scopus
Journal of Agricultural Extension

Vol. 22 (1) February, 2018

ISSN(e): 24086851; ISSN(Print); 1119944X

http://journal.aesonnigeria.org

http://www.ajol.info/index.php/jae

Email: editorinchief@aesonnigeria.org

manage them, the benefits that they will realise and the challenges that they will face from the venture to be undertaken. Entrepreneurs can earn profits as a result of taking risks and the higher the risks, the higher the profits. However, entrepreneurs will always prefer to take on those risks that they can manage.

Persuasion and networking is the ability to link, convince and influence other individuals, agencies and other groups in order to maintain business contacts at a high level. This will help or work for the cause of the business in a positive manner to accomplish own objectives. For persuasion and networking, most of entrepreneurs scored below average as this characteristic recorded the lowest mean score of 1.22. It implies that women had weak abilities to link, convince and influence other individuals, agencies and other groups in order to maintain the wide ranged business network. This may be due to inadequate skill on the part of women. Generally, women entrepreneur were found to be less competent $(\bar{x}=1.97)$ considering all the characteristics measured. This is reflected in the low mean annual income of $208,759.38$ (Table 1). The low competence may not be unconnected with low level of education among the women under study.

Table 3: Entrepreneurial competencies of respondents

\begin{tabular}{llc}
\hline S/No & Entrepreneurial comprtencies & $\begin{array}{c}\text { Competency Mean }(\bar{x}) \\
\text { score }\end{array}$ \\
\hline 1 & Persistence & 2.55 \\
2 & Commitment to the work contract & 2.47 \\
3 & Risk-taking & 2.40 \\
4 & Information-seeking & 1.97 \\
5 & Systematic planning and & 1.96 \\
& monitoring & \\
6 & Opportunity seeking & 1.93 \\
7 & Goal setting & 1.91 \\
8 & Self-confidence & 1.81 \\
9 & Demand for efficiency and quality & 1.45 \\
10 & Persuasion and networking & 1.22 \\
\hline \multicolumn{2}{l}{ Overall } & 1.97 \\
\hline
\end{tabular}

Figures in parentheses are percentages

\section{Constraints to Women Entrepreneurial Development}

Table 4 indicates the constraints to women entrepreneurial development. Finance is the most important aspect of any business. Lack of start-up capital was rated as the biggest constraint (95\%). Non-availability of long-term finance and long procedures to access financial help, where available, have been identified as major constraints faced by women entrepreneurs (Otunaiya and Idowu, 2009; Nwibo and Okorie, 2013; Otunaiya, 
Creative commons User License: CC BY-NC-ND

Abstracted by: EBSCOhost, Electronic Journals Service (EJS), Google Scholar, Journal Seek, Scientific Commons,

Food and Agricultural Organization (FAO), CABI and Scopus
Journal of Agricultural Extension

Vol. 22 (1) February, 2018

ISSN(e): 24086851; ISSN(Print); 1119944X

http://journal.aesonnigeria.org

http://www.ajol.info/index.php/jae

Email: editorinchief@aesonnigeria.org

Ambali and Idowu 2013). During the process of marketing of products, women entrepreneurs are faced with problem of poor location of shop, lack of transport facility and tough competition from larger and established units. Other challenges of women entrepreneurs include inadequate access to relevant information, unavailability and high cost of required machine or equipment, inadequate skill in the line of business and nonavailability of labor. When necessary resources are available to women entrepreneurs, women still hesitate to set up units or do not succeed in their ventures due to constraint imposed on them by their immediate environment such as family commitment (Aculai et al., 2006; Aidis, 2006). According to Labich and deLlosa (1994), investment in agricultural related business especially in the African setting, have been generally agreed to be constrained by lack of market opportunity, access to finance, enabling environment, market information, and managerial skills.

\section{Table 4: Respondents' entrepreneurial development constraints}

\begin{tabular}{lll}
\hline S/№ & Constraints & Percent $^{\star}$ \\
\hline 1 & Lack of start-up capital & 95 \\
2 & Poor infrastructural facilities & 93 \\
3 & Inadequate access to relevant information & 89 \\
4 & Unavailability of machines/equipment & 85 \\
5 & Cumbersome procedure of formal credit facilities & 78 \\
6 & Inadequate storage facility & 67 \\
7 & High cost of inputs & 61 \\
8 & Inadequate skill in the line of business & 59 \\
9 & High labour cost & 57 \\
10 & Scarcity of labour & 52 \\
11 & Low demand for product & 48 \\
\hline
\end{tabular}

*Multiple responses

\section{Conclusion and Recommendations}

The entrepreneurial competency of women entrepreneur was low. Women farmers' entrepreneurial development in Nasarawa State is bedeviled by myriads of constraints. However, they were persistent, committed and risk-bearing. Women entrepreneur have low competency in persuasion and networking, in their demand for efficiency and quality, as well as self-confident.

Various tiers of government should create the enabling social and physical infrastructure environments to catalyze entrepreneurial development (with special focus for women) in the rural areas. Extension agencies should develop training to address 
Creative commons User License: CC BY-NC-ND

Abstracted by: EBSCOhost, Electronic Journals Service (EJS), Google Scholar, Journal Seek, Scientific Commons,

Food and Agricultural Organization (FAO), CABI and Scopus
Journal of Agricultural Extension

Vol. 22 (1) February, 2018

ISSN(e): 24086851; ISSN(Print); 1119944X

http://journal.aesonnigeria.org

http://www.ajol.info/index.php/jae

Email: editorinchief@aesonnigeria.org

(develop) these characteristics in the women in order to ensure entrepreneurial success. This can be achieved better by encouraging the formation (and the management) of cooperative along business line.

\section{References}

Aculai, E., N. Rodionova and N. Vinogradova (2006). Women Business Owners in Moldova: Proprietors or Entrepreneurs? In: F. Welter, D. Smallbone and N. Isakova (Eds.), Enterprising Women in Transition Economies. Ashgate, Aldershot, pp: 67-91.

Aidis, R. (2006). From Business Ownership to Informal Market Traders: The Characteristics of Female Entrepreneurship. In: Lithuania, F., D. Welter, Smallbone and N. Isakova (Eds.), Enterprising Women in Transition Economies. Ashgate, Aldershot, pp: 119-142.

Akanji, O.O. (2001). Microfinance as a strategy for poverty reduction. Central Bank of Nigeria Economic and Financial Review, 39(4), 111-134.

Allens and C. Truman, (1992). Women Business and Self-Employment: A Conceptual Minefield. In: Abers and N. Gilbert (Eds.), Women and working lives. Macmillian, London, pp: 162-174.

Anna, A.L., G.N. Chandler, E. Janson and N.P. Mero, (2000). Women business owners, traditional and nontraditional industries. J. Bus. Venturing, 15(3): 279-303.

Carter, S. and Rosa, P. (1998). The financial of male and female-owned businesses. Entrep. Region. Dev.. 10(3): 225-241.

Carter, S. (2000). Gender and Enterprise. In: Carter, S. and D. Jones Evans (Eds.), Enterprise and Small Business, Principles, Practice and Policy. Addison Wesley.

Idris, A. J. (2015) Effect of social capital on poverty alleviation: a study of women entrepreneurs in Nasarawa state, Nigeria. JORIND 13(1): 208-222 www.transcampus.org/journal; www.ajol.info/journals/jorind. Assessed $6^{\text {th }}$ January 2017.

Matanmi, S. \& Awodun, M. (2005). An assessment of competitive strategies and growth patterns of new enterprises in Nigeria using the developing economy model. Lagos Organisation Review, 1(1), 26-32.

Nasarawa State Agricultural Development Project (NADP) (2010). Annual Reports.

National Population Commission (2006). Census Report of Nigeria. Population and Development Review, 33(1) (Mar., 2007), pp. 206-210 Published by: Population Council Article Stable URL: http://www.jstor.org/stable/25434601. Assessed $7^{\text {th }}$ May 2013.

Nkpoyen, F. and Bassey, G. E. (2012). Micro-lending as an empowerment strategy for poverty alleviation among women in Yala Local Government Area of Cross River State, Nigeria. International Journal of Business and Social Science, 32(18), 233241.

Nwala, M. N. and Alfred (2013) Financing and related constraints to the growth of women entrepreneurship: Evidence from Nasarawa State, Nigeria. Archives of 
Creative commons User License: CC BY-NC-ND

Abstracted by: EBSCOhost, Electronic Journals Service (EJS), Google Scholar, Journal Seek, Scientific Commons,

Food and Agricultural Organization (FAO), CABI and Scopus
Journal of Agricultural Extension

Vol. 22 (1) February, 2018

ISSN(e): 24086851; ISSN(Print); 1119944X

http://journal.aesonnigeria.org

http://www.ajol.info/index.php/jae

Email: editorinchief@aesonnigeria.org

Applied Science Research, 5(6): 165-171. Retrieved from http://scholarsresearchlibrary.com/archive.html 20th February, 2017

Nwibo, S. U. and Okorie, A. (2013) Constraints to entrepreneurship and investment decisions among agribusiness investors in southeast, Nigeria. International Journal of Small Business and Entrepreneurship Research, 1(4): 38-50.

Organization for Economic Cooperation and Development (OECD) (1997). Entrepreneurship and SMEs in transitional economics. The Visegrad Conference, OECD Proceedings Plans.

Organization for Economic Cooperation and Development (OECD) (2013), Youth entrepreneurship. A background paper for the OECD Centre for enterpreneurships, SMEs and local development.

Ogundele, J.J.K., Akingbade, W.A \& Akinlabi, H.B. (2012). Entrepreneurship training and education as strategic tools for poverty alleviation in Nigeria. American International Journal of Contemporary Research, 2(1): 148-156.

Otunaiya, A. O., Ambali, O. I. and Idowu, A. O. (2013) Profitability and constraints analysis of women entrepreneurs in Lagos State, Nigeria. Asian Journal of Business Management, 5(1): 13-18.

Otunaiya, A.O. and Idowu, A. O. (2009). Credit and factors affecting farm incomes in food crop production in yewa north local government area of Ogun state. Nigeria Int. Multidiscip. J. Sci. Res., 2(2): 86-91.

Ruangkrit, S. and Thechatakerng, P. (2015) Characteristics of Community Entrepreneurs in Chiangmai, Thailand. World Journal of Management, 6(1): 58 74.

United Nations Industrial Development Organization (UNIDO) (1995). Integration of women industrial development unit, participation of women in manufacturer patterns. Determinants and Future Trend, Regional Analysis, ECA Regions, Final Report, Vienna.

UNIDO, 2001. Women Entrepreneurship Development in Selected African Countries, Working Papers, No. 7. 